I should like to be informed, by those who can give the information, whether cholera has ever appeared in any town south of the equator; as it appears to me that a line drawn, with a wide margin, from Calcutta to Petershurgh, from thence to the Gulf of Mexico, and from that back again to Calcutta, might be called "the cholera inclosure." I cannot help connecting this with the existence of some circular or elliptical course of wind, including, perhaps, a stagnant field of air in its vortex, if not in its own direct current, bearing the seeds of death.

I am, Sir, your obedient servant,

Watford, Herts, Aug $185 \%$.

EDWARd Cross.

P.S. Can anyone say whether the great mass of weeds growing in the Atlantic between Africa and the Kest Indies increases or otherwise? Also, whether those tornadoes which prevail now and then in those islands exist, or are absent, in a marked way during a cholera-period of the world?

\section{ARSENIC AS A COSMETIC.}

\section{To the Editor of THE LANCE'r.}

SIR,-The note on the above subject which you did me the honour to insert in THE LANCET of the lst inst. has been commented on by two gentlemen in your number for Saturday last. If Mr. Sparling will read over my note again, he will see that it made no reference whatever to the guilt or innocence of the accused, but was written because I imagined that the question regarding the effects of arsenic when applied externally was left in rather an unsatisfactory state after the trial, and that the eminent medical gentlemen who appeared for the defence did not go far enough in their experiments to settle the point, and also because $T$ have seen eruptions on the arms and legs of shepherds, who informed me that they were produced by dipping sheep in water having arsenic stirred up in it. I am well aware that sheep are occasionally dipped in a solution prepared by boiling arsenic with alkalies. Severe eruptions, violent constitutional symptoms, and even death, have followed this process, when too long continued. Various preparations are sold for sheep-dipping, but it is generally believed that arsenic is the chief ingredient. I have seen eruptions produced by using these substances.

The mode of applying arsenic described by Mr. Sparling I have not before heard of. That it was not the very weak aqueous solution of arsenic which came in contact with the hands and faces of the gentlemen who made the experiments referred to above, is evident from the statement of Dr. Laurie, a highly-esteemed former teacher of mine,-viz., that "the effect was the same as using a ball of soap with sand ;" showing that during the agitation of the water in washing the hands and face, some of the gritty particles of arsenic floating about in the water were applied to the skin, just as in the mode of using arsenic in sheep-dipping, referred to in $m y$ former note. Of course the greater the quantity of arsenic used, the more violent the agitation of the water, and the oftener the experiment is made, so much the more severe would be the effect produced.

If my note should be the means of recalling attention to the subject, and of bringing ont any additional information, it will have served some useful purpose.

I am, Sir, yours, \&c.

Peebles, August 10th, 1857. Robert Crawford, M.D.

\section{To the Editor of The Laxcer.}

SIR,--In your journal of the lst instant, Dr. R. Crawford, of Peebles, states that the farmers use various substances for sheep dipping, and amongst others arsenic, and remarks that these sheep dippers frequently have eruptions on the skin. This he considers a satisfactory proof that the medical evidence given for the defence of Miss Smith must go for nought; but he does not state, nor does he seem to know, whetler it was the arsenic, or some of the various other substances employed, that caused these eruptions on the patients he was asked to prescribe for. I am perfectly aware that arsenic is used for the purpose he mentions, and also many other substances, such as the preparations of mercury, zinc, lead, \&c. Now, I ask, is it not possible, or rather probable, that it may be one of these that caused the eruption he mentions, and not the arsenic. But supposing it to be arsenic, according to his own account, the quantity accidentally applied must be large, and the clothes saturated with the solution and filth, and the friction which must be caused by a living sheep half drowned in poison, trying to struggle out of it for life. There can be no comparison between the accidental application and careful voluntary applica. tion intended for a delicate purpose. Every medical men acknowledges that arsenic has a specific action on the skin when used in small doses. Who knows but that arsenic may be nsed empirically for improving the complexion; or with the idea that it does improve it? How many people have used Rowland's preparations with the idea that one removes freckles, and fills up the pitting after small-pox; the other producing hair on a bald scalp, and making old maids look young. Every scientific man knows that this is all hypocrisy. When the physiology of freckles and the formation of pignient is known, the knowledge of the rational use of arsenic will be acquired. I am, Sir, your obedient servant,

August, 1857.

R. P.

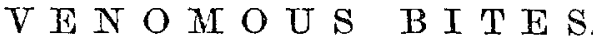
To the Editor of The LANCET.

SIR,-I extract from my note-book, for comparison with the case reported in T'HE LANCET of the 8th instant, the following memoranda made May, 1852, whilst I was house-surgeon to the Westminster Hospital :-

A strongly-built young man was brought in, having been bitten in the right index finger twenty minutes previously by an adder. When I saw him he was hanging his head down, his tongue protruding from his mouth; the face and eyelids were much swollen; there was general cedema of the submucous tissue of the mouth and pharynx, with ptyalism, vomiting, and pain at the pit of the stomach; no pain nor swelling of the hand or arm, but great pain in the right axilla. There was only a faint mark left by the reptile's fang on the finger; no abrasion of the lips or face. Within a few hours the arm and forearm became enormonsly swollen, and the axillary glands inflamed and painful. By the next morning the back and inner part of the arm, and the corresponding side of the chest were much ecchymosed, as though they had been beaten with a stick. The finger was the last to become painful and swell, the symptoms travelling downwards.

The treatment consisted of leeches and fomentations to the throat; fomentations, and subsequent embrocations to the arm, and a saline rnixture.

The swelling of the fauces and arm subsided; the skin of the above-named parts underwent all the stages of bruising. The finger became painful as the other symptoms subsided, and remained tender for some time after. The adder was brought to the hospital for inspection.

$I$ am, Sir, your obedient servant,

Vietoria-square, Aug. 185̌7. GEORGE B. HALFORD, M.D.

\section{HINTS ON SURGICAL PRACTICE. To the Editor of THE LANCET.}

SIr, - Will you allow me to call the attention of the profession to a few practical hints which $I$ have found of great utility in the practice of this hospital.

I have for the last fifteen months been in the habit of putting fractured legs up in pasted paper, when the swelling has subsided, which enables our patients to leave their beds at the end of ten days or a fortnight. I do not claim any originality for the idea, which I saw practised in Paris; but as I have not observed any notice of it in England, and have found it so very useful, I should be glad if it was more extensively known. The advantages it possesses over the starch bandage, of which it is a modification, are, that sloughing from over-pressure is impossible, as on attempting to pull the paper too tight it tears, and the materials for it are always at hand. My mode of procedure is as follows:-I prepare forty or fifty strips of brown paper, an inch and a quarter broad, and sixteen inches long; these are all smeared with thick paste, and applied to the limb in the ordinary manner of strapping. Three layers are applied, a light bandage over all, and then left to dry, supported by sand-bags. The strips are all pasted before any are put on. In twenty-four hours it forms a very hard, light case, exactly applied to the limb, and affords perfect protection during the reparative process. It must be well soaked before removal.

I have lately mixed half a drachn of glycerine to one ounce of extract of belladonna when I have used the latter for dilating the pupil. It renders it pliable and elastic, and does not produce that disagreeable tightness complained of when the simple extract gets dry and hard.

I have also used a darkened tube in the diagnosis of bydro. 1.81 
cele for the last twelve months, and can recommend it as being extremely useful. That which I employ is of tin, blackened within, seven inches long, one inch and a quarter in diameter at its larger end, and tapering to three quarters, where it is furnished with a wooden eye-piece. In sunlight, or in a tolerably translucent hydrocele, a candle can be dispensed with, as sufficient light makes its way through to reveal the nature of the swelling.

Having now, by the kindness of the surgeons of our hospital, Messrs. Terry and Mash, given the foregoing modes of procedure a very extensive trial, and having been very successful in their results, I am anxions that others should become acquainted with them, and suggest any improvements which may occur to them. - I am, Sir, your obedient servant,

July, 1857 . JohN C. SA VERY, M.R.C.S.E.

House Surgeon to the Northampton Gener al Infirmary

\section{Aleviral 赵éws.}

Royal College of Surgeons.-The following gentlemen, having undergone the necessary examinations for $t$ Diploma, were admitted members of the College at the meeting of the Court of Examiners on the 7th inst.:-

Aseury, Charles John, Enfield.

Bodilly, James Broad, Penzance, Cornwall.

Booth, SAM uEL, Huddersfield, Yorkshire.

Buckmaster, William, Middleton, Cork.

Coop: R, Geoffrey Veel, Bristol.

CUlverwell, Charles, Arundel-street, Strand.

HINDER, JoHN, Calcutta.

Rine, Richardson, Jersey.

Nunar, James Casey, Croome, Limerick.

Stacey, Georee, Hornsey.

Webi, Henry Janes, Cheadle, Staffordshire.

The following were also admitted members on the 10 th inst. :-

AlleN, Wm. Christopher, South Shields.

Curtis, Alrbert, Staines.

Ellis, WM. JAMES, Calcutta.

Tulot"r, CharLes James, Manchester.

Lee, Newton Bolle Colborne, Landon.

McGrath, Henry F, Jamaica.

Pater, WM. Thompson, Canterbury.

WooDs, JoHN, Newry.

Licentiates IN MrDwIFERY.-The following members of the College, having undergone the necessary examinations, were admitted Licentiates in Midwifery at the meeting of the Board of Examiners on the 12th inst. :-

Alcock, JoHn, Cobridge, Staffordshire.

BANNIS'TER, AJFRED JAMES, Chelsea.

Barker, Samuel, Ramsgate.

Bryght, Richard Stonhewer, Richmond.

CoBbeTt, RoBert NuWBERRY, Winchmore-hill.

Crossley, William HENRY, Wath-upon-Dearn, Yorkshire.

DUCHeSNe, RoBert, White Lion-street, Norton Folgate.

Fluder, Charles John, Lymington, Hants.

Harley, Thomas, Cleobury Mortimer, Salop.

Harris, EDWARD, Calcutta.

HiNDER, JohN, Calcutta.

Hoge, Francis Robert, Gower-street.

Mason, Benjamin Earnshaw, Calcutta.

Newman, Augustus, Oxford.

Philpoter, Henry Grax, Brighton.

Radlex, William Hepworth, Doncaster.

Rose, GEorge CowPER, West-square, Lambeth.

Scotr, Thomas Alexander Fraser, Aberdeen.

Simms, Frederick, Tonbridge-place.

Whitefield, Artiur, Barnstaple, Devon.

WirkEs, GEORGE, Stepney.green.

Apothecarres' Hall. - Nanes of gentlemen who passed their examination in the science and practice of Medieine, and received certificates to practise, on

Thursday, August 6th, 1857.

Balding, Charles Culledge, Barkway, Herts

Brayton, Jonathan, Cumberland.

Burrows, Rost. Thos., Westbourne-park-place.

Carter, Henry, Gloucester.

Chartres, John Smith, London.

GarevtT, JoHn MitcheLL, Drinstow Lodge, Gateshead.

Nixon, Geo. Forees, Wigton, Cumberland.

182
University of London. - M.B. First Examina. TION. - The following is a list of candidates who passed the first examination for the degree of M.B., lately held:-

FIRST DIVISION.

Adams, Namuel Hoppus, University College.

AlFord, HenRY James, Unjversity College.

CARTER, RoBerT, University College.

Cayley, William, King's College.

CoOke, JoHr, St. Thomas's Hospital

Cousins, JoHN W ARD, St. Thomas's Hospital.

Crowfoot, WM. Minler, St. Bartholomew's Hospital.

Durham, Arthur Edward, Guy's Hospital.

Harley, John, King's College.

Hickman, Wilimam, University College.

Hill, Matthew Berkeley, University College.

Hind, John Marriott, University College.

JEFFCOAT, JAMES HENRY, St. Mary's Hospital.

Kempster, Felix Henry, University College.

Knaggs, Henry, Guy's Hospital.

Langdon, Thos. CHas., St. Bartholomew's Hospital.

LloYd, EDWARy HARFord, London Hospital.

Marriott, Cerarles Haxes, University College.

Moxon, Walter, Guy's Hospital.

Pemberton, C. I. H., Queen's College, Birmingham.

Pile, William, University College.

Ringer, Sydnex, University College.

RivingtoN, WaITER, London Hospital.

Rix, William Howelis, Middlesex Hospital.

Smitm, Eustace, University College.

Thompson, Edmunn Symes, King's College.

SECOND DIVISION.

Buch inan, Albert, B.A., University College.

Copestake, Walter, St. George's Hospital.

Everet, Wilton, London Hospital.

Gasquet, Joseph Raymond, University College.

Harvey, Charles Hammton, King's College.

Sansom, Arthur ERNest, King's College,

Shepherd, JaMes, University College.

Squire, Alex. John B., University College.

Stokoe, Paur Henry, Guy's Hospital.

Development of the Frontal Sinuses.-We have been shown very beautiful photographs of sections of the frontal bone, illustrating the development and the varying capacity of the sinuses. These illustrations are extremely interesting, as they afford actual, very carefully-collected data respecting the development and capacity of the sinuses, on which our knowledge was hitherto imperfect. Mr. Willmott, anatomical modeller to St. Mary's Hospital, to whose patient investigation and zeal we owe the sections and photographs, states that "in some young male and female adults the sinuses are very largely formed, and appear to have been developed somewhat in proportion to the growth of the bones of the head; whereas with some at the same age it is very small and irregnlar, and in a few no sinuses at all exist above the supra-orbital processes." Hence it appears that great irregularity prevails in this respect, the proportion being one frontal bone without sinues to six or eight presenting such cavities, in all the skulls of which Mr. Willmott has made sections. The photographed diagram also shows that the capacity of sinuses differs considerably, some being sufficiently large to hold one ounce and a half of fluid, the others hardly admitted one drachm. The knowledge of these facts may certainly be of service to the surgeon in wounds about the forehead, whether gun-shot or others. Nor must it be overlooked, that no correct idea of the shape of the brain in this situation can be formed, considering the existence of such irregularities as regards the capacity of the sinuses. Mr. Willmott's sections and illustrations will be found of great service to all those interested in anatomical science.

A Domestic Detonator.-The number of accidents occurring in Paris from the common employment of gazogenes, or machines charged with aërated waters, has been so great, as to attract the attention of the Society of Surgery. At a late meeting, upwards of twenty cases were recorded of explosion, with all the force of a gun, of these machines, the frag. ments causing in some cases very severe wounds. The employ. ment of aërated waters is always grateful, and often very beneficial. They are gradually coming more generally into use in England, and would be still more commonly employed but for the exorbitant sums charged for the machines by London, compared to Paris, traders. We think it right to direct attention to the necessity of caution in using gazogenes, especially when they are just charged. 